\title{
A Passagem Interna da Modernidade para a Pós-modernidade
}

The inner transition from modernity to post-modernity

Resumo: A passagem da modernidade para a pós-modernidade vem sendo intensamente estudada de uma perspectiva macro, ou social. São, no entanto, poucos os estudos que procuram compreender como está dando-se essa transição do ponto de vista micro, ou individual. Esse é o objetivo do presente trabalho. Uma análise do discurso de jovens entre 18 e 25 anos sobre o seu uso de telefones celulares deu visibilidade parcial a essa transição interna e permitiu identificar um processo de interpenetração de campos semânticos que dá concretude psicológica a algumas das principais características do mundo contemporâneo: seu imediatismo e sua fluidez.

Palavras-Chave: Modernidade, pós-modernidade, celulares, jovens.

Abstract: The transition from modernity to post-modernity has been intensively studied from a macro, or social, perspective. There have been, however, few attempts to understand how such a transition is taking place from a micro, or individual, point of view. This is the main purpose of the present study. An analysis of 18 to 25-year-old men and women's discourse about their use of cell phones made this inner transformation partially visible. This analysis made it possible to identify a process of interpenetration of semantic fields that makes some of the main characteristics of the post-modern world - its immediacy and fluidity - psychologically concrete.

Key Words: Modernity, post-modernity, cell phones, young people.

\section{Ana Maria Nicolaci-da-Costa \\ Psicóloga. M.A. em Psicologia pela New school for Social Research em Nova York. Ph.D. em Psicologia pela Universidade de Londres. Professora e pesquisadora do Departamento de Psicologia da PUC-Río.}

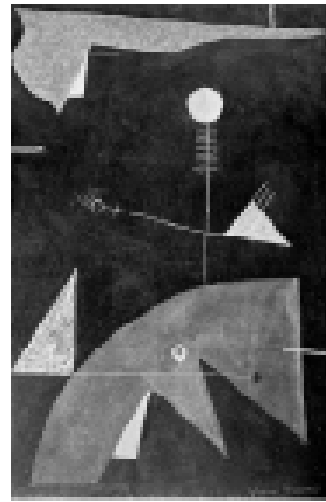

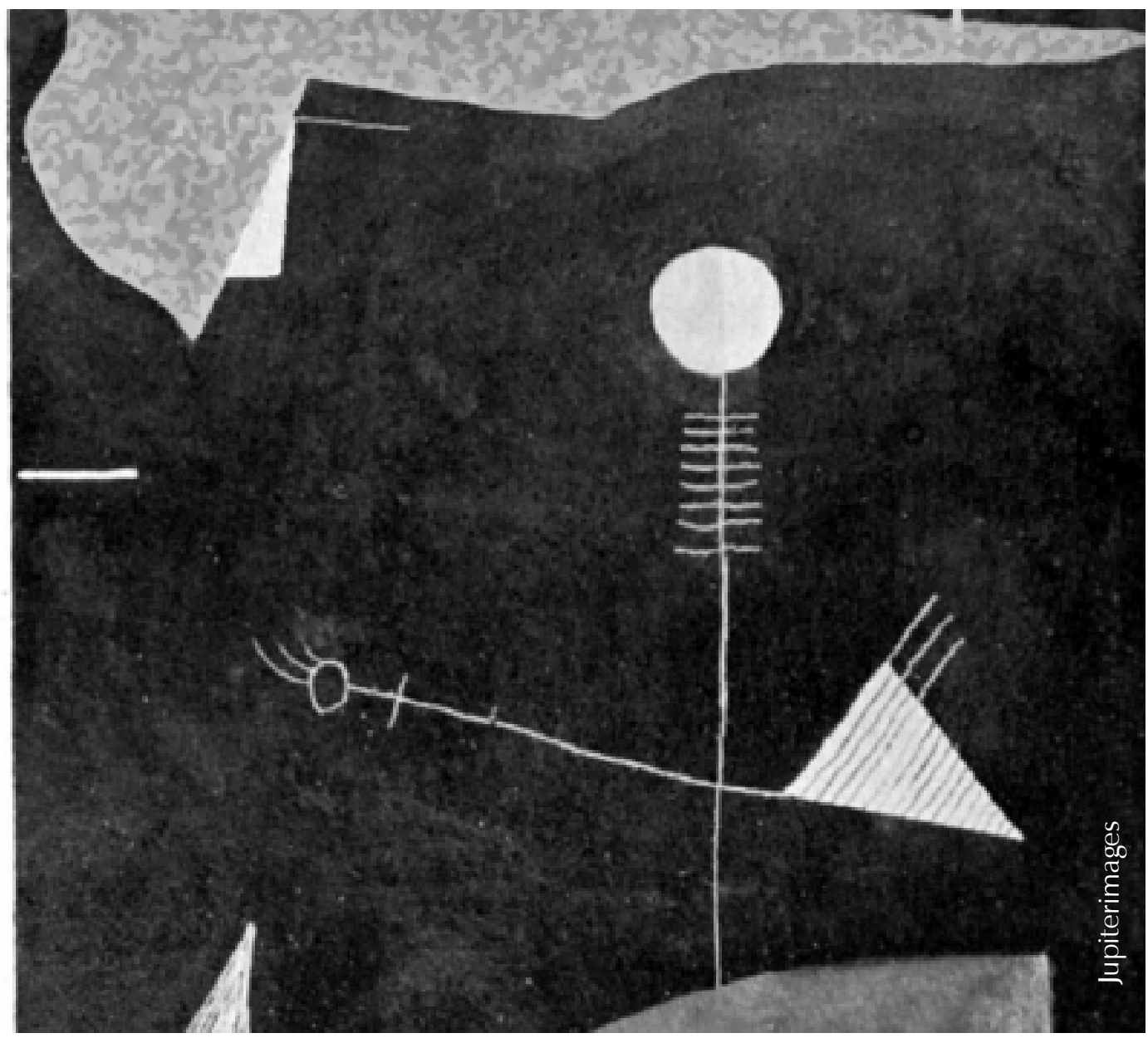


As profundas transformações sociais pelas quais o mundo vem passando nas últimas décadas têm sido objeto de investigação de intelectuais de diversas áreas, notadamente da Sociologia e da Filosofia. Geralmente realizadas a partir de macro perspectivas, essas investigações vêm contribuindo para que tenhamos uma visão panorâmica tanto da trama quanto da dinâmica da nova organização social. Têm também possibilitado a apreensão cada vez mais acurada da realidade característica deste novo milênio.

Por conta de interesses e formação intelectual variados, no entanto, diferentes autores dão diferentes nomes de batismo a esse mesmo conjunto de transformações (às vezes, um mesmo autor dá mais de um): revolução das tecnologias da informação (Castells, 2000), pós-modernidade ou pós-modernismo (Lyotard, 1979, Vattimo, 1985, Jameson, 1991, Bauman, 1998, 2001, Harvey, 1989, Eagleton, 1996), modernidade líquida (Bauman, 2001), capitalismo tardio (Jameson, 1991), capitalismo flexível (Sennett, 1998, Bauman, 2001) etc. Essas diferenças de nomenclatura refletem, ao menos em parte, as divergentes ênfases dadas por esses analistas aos vários aspectos que fazem parte do atual processo de mudança (essas diferenças são exploradas em Leitão e Nicolaci-da-Costa, 2003). Para alguns, os avanços tecnológicos são determinantes do quadro de mudanças atual. Para outros, esse papel central é desempenhado por fatores econômicos. Para muitos, a mudança representa uma ruptura com o que veio antes; para outros tantos, essa mesma mudança é apenas um outro estágio da velha ordem.

Para os propósitos da presente discussão, contudo, essas diferenças não são cruciais e serão deixadas de lado de modo a facilitar a exposição. A denominação única de pós-modernidade será adotada pela simples razão de que torna o contraponto entre o período pós-moderno e o moderno mais claro e acessível. Esse contraponto, que está presente - de modo mais ou menos explícito - na maior parte das abordagens mencionadas acima, desempenha um importante papel no raciocínio que se segue. Isso porque dá visibilidade às características distintivas da velha e da nova ordem, bem como possibilita a apreensão da passagem de uma para outra.

Este estudo apropria-se do conhecimento dessas características e dessa passagem, já produzido no plano macro, com um intuito particular: o de procurar apreender como se dá a passagem da modernidade para a pós-modernidade do ponto de vista micro (ou individual). Seu objetivo é o de identificar e trazer à tona algumas transformações psicológicas que estão ocorrendo como conseqüência das turbulentas mudanças ora em curso.

\section{Características da Modernidade e da Pós-Modernidade}

Ordem, progresso, verdade, razão, objetividade, emancipação universal, sistemas únicos de leitura da realidade, grandes narrativas, teorias universalistas, fundamentos definitivos de explicação, fronteiras, barreiras, longo prazo, hierarquia, instituições sólidas, poder central, claras distinções entre público e privado etc.

Essas são algumas das características que a maior parte dos analistas da pós-modernidade atribui à modernidade. São, portanto, características de uma realidade que muitos de nós conhecemos de perto, mas que muito provavelmente sequer saberíamos colocar em palavras poucas décadas atrás. Então, ainda faltava-nos a visibilidade dada pelo contraponto entre a velha e a nova realidade. Tínhamos, principalmente no período que se seguiu à 2a Guerra Mundial, apenas a vaga e confortável sensação de que o mundo em que vivíamos era estável. Essa sensação foi abalada pelos processos de mudança que deram a esse mesmo mundo suas feições pós-modernas.

Algumas dessas feições são tão evidentes a ponto de não gerarem discordâncias, mesmo quando vistas a partir de diferentes convicções políticas ou abordagens teóricas, e é novamente o contraponto entre as duas realidades que torna essas feições tão evidentes e consensuais. Entre elas, destacam-se as seguintes: a globalização, as comunicações eletrônicas, a mobilidade, a flexibilidade, a fluidez, a relativização, os pequenos relatos, a fragmentação, as rupturas de fronteiras e barreiras, as fusões, o curto prazo, o imediatismo, a descentralização e extraterritorialidade do poder, a imprevisibilidade e o consumo.

Eagleton (1996) resume alguns dos atributos distintivos dos períodos moderno e pós-moderno de forma bastante eficaz quando diz:

"Pós-modernidade é uma linha de pensamento que questiona as noções clássicas de verdade, razão, identidade e objetividade, a idéia de progresso ou emancipação universal, os sistemas únicos, as grandes narrativas ou os fundamentos definitivos de explicação. (...) vê o mundo como contingente, gratuito, diverso, instável, imprevisível, um conjunto de culturas ou interpretações desunificadas gerando um certo grau de ceticismo em relação à objetividade da verdade, da história e das normas, em relação às idiossincrasias e à coerência de identidades" (p.7).

Bauman (2001) usa outros adjetivos para qualificar os períodos moderno e pós-moderno, mas, em última análise, aponta basicamente as mesmas
Agradecimentos: Da pesquisa relatada neste artigo, participaram as seguintes alunas: Erika Falcão Ramalho, Maria Engel de Oliveira, Claudia Puntel Pereira dos Santos, Carolina de Sousa Aguiar Figueiredo, Roberta Beckowski, Daniella Muller de Campos Dantas Brasil. Várias foram bolsistas de iniciação científica do CNPq (PIBIC) e FAPERJ.

1 As pesquisas em Psicologia Clínica que utilizam essas vias, no entanto, ainda não são muitas (ver Leitão e Nicolacida-Costa, 2000, e Leitão, 2003).

2 Alguns desses estudos como, por exemplo, os de Plant $e$ Rheingold - tinham por objetivo investigar o uso dos celulares em diferentes partes do mundo, enquanto outros se concentraram em investigar os usuários de uma mesma cidade (Kopomoaa) ou de uma mesma nacionalidade (Roberts, Crabtree \& Nathan).

3 Todos os nomes são fictícios.

4 Observe-se que o passar mal, que tradicionalmente definiria uma emergência, é colocado no final da lista de emergências de Bianca. 
características desse estágio do capitalismo flexível: o poder extraterritorial, as comunicações eletrônicas, a instantaneidade, a instabilidade etc. Em um trecho do seu recente Modernidade Líquida, ele resume essas características compactamente:

"[A modernidade clássica] parece 'pesada' (contra a 'leve' modernidade contemporânea); melhor ainda, 'sólida' (e não 'fluida', 'líquida' ou 'liquefeita'); condensada (contra difusa ou 'capilar'); e, finalmente, 'sistêmica' (por oposição a 'em forma de rede')" (p. 33).

"Uma característica central da nossa era global é uma crescente permeabilidade da maior parte das fronteiras físicas, sociais, políticas, culturais $e$

econômicas. Isto é, a maior parte das membranas naturais ou produzidas pelos homens estão se tornando porosas, às vezes tão porosas a ponto de desaparecer funcionalmente"

Meyrowitz
Deleuze \& Guattari (1997) também oferecem metáforas, imagens e definições que ajudam a visualizar o que mudou na passagem da modernidade para a pós-modernidade. Partindo de uma concepção bastante idiossincrática e abrangente de espaço (concepção essa que inclui a organização e a dinâmica da vida em sociedade), fazem uma comparação entre o espaço estriado, que, segundo eles, caracteriza a modernidade, e o espaço liso, que predomina no período pósmoderno. O espaço estriado, como um tecido com suas tramas verticais e horizontais, é bem demarcado e sedentário (ou "sólido" e "pesado", na terminologia de Bauman); já o espaço liso, como o feltro, não tem demarcações e é nômade (características que correspondem à "leveza" e "fluidez" descritas por Bauman). Deleuze \& Guattari deixam claro, no entanto, que esses dois espaços podem interpenetrar-se e transformar-se um no outro (o que obviamente implica dizer que convivem lado a lado).

Retomando o que nos dizem Eagleton, Bauman e Deleuze \& Guattari, enquanto a modernidade era sólida e estriada, em virtude da visibilidade de seus poderes centrais, hierarquias, regras, barreiras, fronteiras etc., a pós-modernidade é fluida, ou lisa, em virtude de sua descentralização, organização em redes, sua ausência de barreiras ou fronteiras. Vários dos aspectos que caracterizavam o período moderno estão em via de desaparecer. Esse desaparecimento, porém, não acontece da noite para o dia. Ele é o resultado de, entre outros, vários processos de fusão e diluição discutidos por Meyrowitz (1999), que faz uso de metáforas bem diferentes daquelas usadas por Bauman e Deleuze \& Guattari. Enquanto as metáforas usadas por estes enfatizam estados que antecedem ou sucedem as mudanças, as de Meyrowitz colocam em relevo os processos de mudança em si mesmos.

A atenção de Meyrowitz concentra-se na atual interpenetração de áreas e experiências consideradas distintas no período moderno (como, por exemplo, as das disciplinas que correspondem à divisão do saber da era moderna ou das experiências consideradas públicas e privadas). Seu argumento central é o de que:
"Todo sistema natural e social é definido por suas membranas - aquilo que separa o que 'ele é' daquilo que 'ele não é'. Do organismo mais simples ao incrivelmente complexo ser humano, de uma gangue a uma corporação, as fronteiras entre o interior e o exterior são características básicas" (p. 45).

Em contraste com a relativa impermeabilidade das membranas do período moderno, Meyrowitz afirma que:

"Uma característica central da nossa era global é uma crescente permeabilidade da maior parte das fronteiras físicas, sociais, políticas, culturais e econômicas. Isto é, a maior parte das membranas naturais ou produzidas pelos homens estão se tornando porosas, às vezes tão porosas a ponto de desaparecer funcionalmente" (p. 45).

Essa metáfora das membranas impermeáveis que se tornam porosas procura registrar a dinâmica por meio da qual as diferentes características da modernidade se liquefazem, se fundem e se interpenetram dando origem à pós-modernidade, ou seja, procura dar visibilidade ao processo que transforma o aparentemente sólido e estático mundo moderno no fluido e dinâmico mundo pós-moderno. Pressupõe, portanto, a convivência de ambos os mundos, pelo menos no atual estágio da mudança.

\section{A Passagem do Macro ao Micro}

Do ponto de vista do que acontece no plano individual, a literatura recente também vem convergindo em torno de pelo menos uma certeza, a de que o ser humano está sofrendo profundas alterações em conseqüência dos processos que vêm transformando o mundo moderno em pósmoderno.

Mesmo dentro de suas macroanálises, alguns sociólogos e filósofos procuram dar conta do que acontece no plano pessoal. No mais das vezes, identificam conseqüências e sentimentos gerais como, por exemplo, a incerteza, a insegurança, a ansiedade, o medo etc. - gerados pela nova realidade (ver, entre outros, Bauman, 1997, Sennett, 1998, Harvey, 1989, Virilio, 1993). Em alguns casos, registram também conflitos psicológicos e descrevem características centrais da nova dinâmica subjetiva. Sennett (1998), por exemplo, registra conflitos psicológicos que já podem ser facilmente detectados, como aqueles relativos à incompatibilidade entre os projetos de vida a longo prazo e o imediatismo do trabalho no novo capitalismo flexível. Enquanto isso, Jameson (1991), um crítico de arte que se tornou um dos maiores analistas da pós-modernidade, aponta a fragmentação da mônada característica do 
individualismo moderno como um dos aspectos distintivos da subjetividade pós-moderna. Já Bauman (1997) e Sennett (1998) enfatizam a posição de destaque que a necessidade de satisfação imediata do desejo ocupa na dinâmica subjetiva contemporânea, em contraposição ao imperativo moderno do seu adiamento.

Saber o que está acontecendo no íntimo das pessoas em um momento de mudanças como o atual não é, porém, o principal propósito de sociólogos, filósofos ou críticos de arte (por isso mesmo, suas análises raramente se aprofundam o suficiente). A produção desse tipo de conhecimento é da alçada de outros pesquisadores. É, na realidade, um dos objetivos centrais de muitos pesquisadores em Psicologia Clínica. Estes, no entanto, enfrentam um sério desafio: o de tornar possível a captação dos processos de transformação internos.

Uma via de acesso a esses processos de transformação internos, que vem sendo utilizada com bastante sucesso, é a da investigação de como os homens, mulheres e crianças contemporâneos estão fazendo uso das novas tecnologias de comunicação, que, todos admitem, desempenham um importante papel nos processos de mudança atuais.

A análise do uso de diferentes tipos de tecnologia (principalmente de ambientes interativos na Internet) e dos discursos sobre esse uso proferido por diferentes tipos de sujeito tem-se mostrado valiosa na apreensão tanto de conflitos internos quanto daquilo que está em mutação dentro desses sujeitos (ver, entre outros, Turkle, 1995 e Romão-Dias, 2001) ${ }^{1}$.

Dentre esses trabalhos, alguns (ver, por exemplo, Nicolaci-da-Costa, 2002b e 2002c, Romão-Dias 2001, Leitão, 2003) parecem trazer à tona a coexistência de valores modernos e pós-modernos no íntimo dos homens e mulheres contemporâneos. Diferentemente do caso de conflitos aparentes, passíveis de apreensão por outros tipos de pesquisa, fazem-no por meio da investigação aprofundada de indicadores externos de conflitos internos de cuja existência os próprios sujeitos muitas vezes não têm consciência.

São ainda mais raros os trabalhos que, por felicidade, conseguem captar, além desse tipo de conflito, os próprios momentos de transformação de significados e valores internos. Um destes é particularmente relevante para a presente discussão por ilustrar bastante bem um momento como esse no que diz respeito à passagem psicológica da modernidade para a pós-modernidade.
Em pesquisa recente, Nicolaci-da-Costa (2002b) tinha como objetivo investigar como usuários intensivos da Internet lidam com o rótulo de vício, que é freqüentemente atribuído ao seu comportamento de passar longos períodos de tempo em programas interativos online. Os resultados desse estudo revelam um interessante deslizamento de sentido no conceito de vício, deslizamento esse que, por sua vez, parece ilustrar bastante bem o processo de incorporação de novos valores ainda não totalmente desvinculados de antigos conceitos. Embora todos os sujeitos da pesquisa admitissem ser "viciados" (o que revela o quanto ainda estavam presos a antigos conceitos), todos eles, a exemplo do que Giddens (2002) registra em um de seus últimos livros, demonstravam já haver redefinido o significado de vício. Seus discursos bem-humorados e irônicos tornavam evidente que, para eles (tal como para Giddens), quase todas as formas de excesso contemporâneas - como, por exemplo, o da prática intensiva de exercícios físicos vistos como saudáveis - podem ser qualificadas como vícios (o que demonstra que o conceito de vício sofreu uma redefinição).

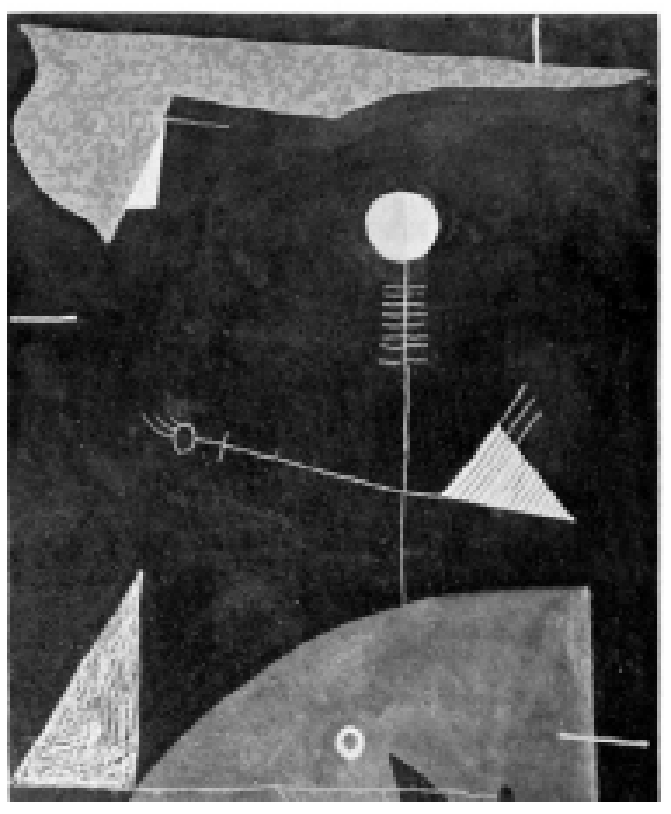

Uma via de acesso a esses processos de transformação internos, que vem sendo utilizada com bastante sucesso, é a da investigação de como os homens, mulheres e crianças contemporâneos estão fazendo uso das novas tecnologias de comunicação, que, todos admitem, desempenham um importante papel nos processos de mudança ałuais.
No que se segue, será exposta uma outra ilustração desses processos. Essa ilustração terá por base uma pesquisa realizada com jovens usuários de aparelhos celulares.

\section{A Pesquisa}

São poucos os estudos que já se dedicaram a investigar os impactos que os celulares estão gerando sobre seus usuários. Dentre eles, os mais conhecidos (porque amplamente divulgados na Internet) são, em grande parte, registros etnográficos 
(alguns realizados por encomenda de empresas de telefonia celular) do uso que diferentes tipos de usuários - de diferentes nacionalidades e diferentes faixas etárias, classes sociais e profissões - fazem de seus celulares (ver, por exemplo, Plant, 2002, Rheingold, 2002, Kopomoaa, 2000, Roberts, Crabtree \& Nathan, 2003).

Apesar de seus diferentes objetivos e das diferentes populações que tinham por finalidade investigar, esses estudos pioneiros revelam alguns resultados interessantes, embora pouco aprofundados. Revelam, por exemplo, que o uso dos vários recursos disponíveis nos celulares (identificação de chamadas, toques individuais, vibracall, mensagens de texto etc.) vem sendo regulado por normas sociais e culturais que estão sendo construídas na medida em que a telefonia celular se difunde. Mostram, também, que o uso de celulares vem modificando a organização e a administração da vida em família (através, por exemplo, da possibilidade de controle à distância dos filhos e da casa) e em sociedade (como no caso da formação de verdadeiras tribos virtuais). Constatam, ainda, que as formas de usar essa nova tecnologia são altamente sensíveis a características culturais, etárias e profissionais. Mesmo assim, quase invariavelmente seus maiores usuários são os profissionais ligados às próprias tecnologias de telecomunicação e os jovens.

Esse conjunto de resultados gera problemas e, ao mesmo tempo, indica caminhos para uma investigação exploratória dos impactos psicológicos dos celulares sobre usuários brasileiros. Entre os problemas, estão a superficialidade desses achados (podemos saber como os celulares são usados sem saber quais as modificações internas geradas por esses usos) e sua validade duvidosa para o caso brasileiro (na medida em que não podem ser generalizados para além de seus contextos de origem).

Apesar dessas restrições, porém, se complementados pela observação cotidiana e por aquilo que é divulgado na mídia, esses resultados sugerem que as populações jovens das grandes metrópoles podem ser um bom ponto de partida para uma investigação dos impactos dos celulares no Brasil, isso porque, tal como em outros grandes centros urbanos (como Tóquio, Helsinki e Londres), os jovens urbanitas brasileiros estão certamente entre aqueles que mais fazem uso dessa nova tecnologia (isso é visível a olho nu). Além disso, uma pesquisa com jovens, que ainda vivem com seus familiares, tem a vantagem de permitir a investigação de questões de interesse central para a Psicologia: as novas formas de organização da família, as novas formas de controle dos pais sobre os filhos, a relativa independência destes em relação àqueles, as alterações que ocorrem na esfera de sua sociabilidade e privacidade (dado que ambas passam a escapar do controle dos pais) etc.

No que se segue, é feito um relato das diversas etapas de uma pesquisa exploratória guiada por esses princípios gerais. Diferentemente dos estudos etnográficos de amplo escopo discutidos acima, essa pesquisa tinha por objetivo não somente registrar como jovens brasileiros usam seus celulares, mas principalmente apreender os impactos psicológicos gerados por esse uso. Era necessário, portanto, que se concentrasse em torno de um pequeno grupo de usuários de modo a atingir a profundidade desejada.

\section{Metodologia}

\section{Sujeitos}

Dada a decisão de estudar a fundo um grupo específico de sujeitos, foram estabelecidos alguns critérios de recrutamento: (a) os sujeitos deveriam ser jovens entre 18 e 25 anos; (b) para que fosse possível apreender os impactos do uso da nova tecnologia, deveriam ter bastante experiência no uso dessa tecnologia, por isso, deveriam ter celular próprio há no mínimo um ano; (c) para assegurar que teriam aparelhos com recursos sofisticados, deveriam pertencer a camadas sociais de médio a alto poder aquisitivo; (d) para que pudessem fornecer dados a respeito de possíveis alterações na organização e administração familiar, deveriam morar com outras pessoas (pais, avós etc.); (e) todos os sujeitos deveriam viver na cidade do Rio de Janeiro, lugar da realização da pesquisa. Não foram feitas quaisquer restrições a sexo ou profissão. Esses dados foram, no entanto, coletados.

Com base nesses critérios, foram recrutados vinte sujeitos - 14 mulheres e 6 homens - a partir de indicações de usuários conhecidos dos pesquisadores. À exceção de uma advogada de 23 anos e de um auxiliar de escritório de 22, todos eram estudantes de $2^{\circ}$ ou $3^{\circ}$ grau. Todos moravam com um ou mais membros da família. Suas idades variavam entre 18 e 25 anos (a média era de 21 anos) e seu tempo de uso de celulares entre 2 e 9 anos (a média era de 4 anos).

\section{Coleta de Dados}

Os dados foram coletados por meio de vinte entrevistas individuais de cerca de uma hora de duração. De modo a torná-las informais e descontraídas, todas as entrevistas foram realizadas em locais escolhidos pelos próprios sujeitos. Tal procedimento foi adotado porque, para investigar a fundo o que é dito pelos entrevistados, é fundamental que eles não se sintam inibidos e possam abrir-se com o entrevistador (a esse respeito ver, por exemplo, Labov, 1973, e Nicolaci-da-Costa, 1989). 
Para guiá-lo, o entrevistador dispunha de um roteiro construído com base nos objetivos exploratórios da pesquisa (a respeito da construção de roteiros, ver Nicolaci-da-Costa, 1989). O roteiro era composto de 30 itens principais que serviram de base para as perguntas. Estas eram formuladas durante a própria entrevista para evitar que fossem lidas e, em conseqüência, soassem artificiais (a entrevista deveria assemelhar-se, tanto quanto possível, a um bate-papo informal). Esses 30 itens/ perguntas poderiam ser desmembrados em outros, para maior aprofundamento. A maior parte desse roteiro era composta de itens/perguntas abertos (que permitem qualquer tipo de resposta). Quando necessários, eram incluídos itens/perguntas fechados (cujas respostas são sim e não), sempre seguidos de perguntas de aprofundamento, como: "por quê?"; "como?"; "onde?", "dá para explicar melhor?".

Os itens/perguntas do roteiro eram agrupados em blocos que abordavam os seguintes tópicos: as diferenças entre o telefone fixo e o celular, a rotina de uso do celular do entrevistado, como este se relacionava com o seu celular (como se sentia quando o emprestava, quando os outros mexiam nele, quando o esquecia ou não funcionava etc.), e, finalmente, como o entrevistado via a privacidade e a intimidade na era do celular.

Para que o leitor possa ter uma idéia de como era construído esse roteiro, seguem-se os itens/perguntas do primeiro bloco, que são os que mais interessam à presente discussão.

Diferenças entre o telefone fixo e o celular: quais as principais diferenças entre o telefone fixo e o celular, quando usa um ou o outro (por que), qual telefone dá primeiro (por que), qual usa para conversas privadas (por que), para qual os amigos ligam primeiro (por que), para qual o entrevistado liga primeiro quando quer falar com os amigos (por que), para qual o entrevistado liga primeiro quando não tem intimidade com o interlocutor (por que), para qual liga primeiro quando tem intimidade (por que).

\section{Análise dos Dados}

Todas as entrevistas foram integralmente transcritas e submetidas às técnicas de análise qualitativa de discurso, desenvolvidas por Nicolaci-da-Costa (1989; 1994; ver também Nicolaci-da-Costa, 2002 b e c). De forma muito resumida, essa análise é realizada em duas grandes etapas. Na primeira a da análise intersujeitos -, são reunidas todas as respostas de todos os sujeitos a cada um dos itens/ perguntas, o que propicia uma visão panorâmica dos depoimentos gerados por cada um desses itens/perguntas. As respostas recorrentes nos discursos coletados e analisados nessa etapa já nos apontam os primeiros resultados - ou seja, as tendências centrais das respostas dadas pelo grupo como um todo -, embora estes ainda sejam inconclusivos. Já na segunda etapa - a da análise intra-sujeitos -, tomam-se as respostas de cada um dos sujeitos como um único conjunto dentro do qual são analisados possíveis conflitos de opiniões, inconsistências entre respostas, sentimentos contraditórios etc. Com o insight ganho nessa segunda etapa, retorna-se à primeira e reanalisamse os conjuntos das respostas dadas por todos os sujeitos a cada uma das perguntas. Esse vai-e-vem (que pode ser repetido quantas vezes necessário) permite que o material coletado seja dominado a fundo e torna possível detectar, além de vários nãoditos (pois o que não é verbalizado em uma resposta pode ser claramente sugerido em outra), os pormenores de sentimentos, conflitos internos e porquês que a pesquisa se propõe a revelar.

\section{Resultados Relevantes}

Dos muitos resultados obtidos, serão apresentados nesta seção apenas aqueles considerados relevantes para a identificação da anteriormente discutida passagem da modernidade para a pósmodernidade do ponto de vista daqueles que por ela são afetados. Antes, porém, cabe fornecer ao leitor uma visão geral dos depoimentos obtidos. Os depoimentos dos nossos entrevistados parecem estar em sintonia com o turbulento período de transformações que estamos vivendo. São, em sua maioria, extremamente confusos e contraditórios. Justamente por conta desse pano de fundo, os pontos que apresentam em comum ganham um relevo especial.

Alguns de nossos sujeitos mal se lembram da época em que os celulares não existiam de tão rápida foi a sua difusão. Uma entrevistada, por exemplo, afirma:

"Eu tinha onze [anos]... eu lembro que meu motorista... já tinha, porque se a gente precisasse falar com ele ligava de um orelhão pra ele. As amigas não, eu acho que na época de colégio não tinha isso. Eu me lembro pouco da época sem celular" (Carla Nóbrega, 21 anos, estudante de Psicologia, tem o celular há mais ou menos quatro anos).

Mesmo assim, nossos jovens sujeitos parecem darse conta das mudanças introduzidas no uso que fazem de celulares pela popularização e conseqüente barateamento de aparelhos e serviços de telefonia móvel.

Desde o início, os custos (com os quais seus pais tinham que arcar) foram sua principal preocupação. Por essa razão, observações sobre custos aparecem em todas as entrevistas. Essa
"Eu tinha onze [anos]... eu lembro que meu motorista.. já tinha, porque se a gente precisasse falar com ele ligava de um orelhão pra ele. As amigas não, eu acho que na época de colégio não tinha isso. Eu me lembro pouco da época sem celular" (Carla Nóbrega, 21 anos, estudante de Psicologia, temo celular há mais ou menos quatro anos). 
preocupação foi, no entanto, amortecida com a popularização do uso dos celulares e a conseqüente redução nas tarifas de serviço dos mesmos.

"Ah...eu acho que no começo eu fazia um racionamento de celular... Hoje em dia não penso duas vezes quando vou ligar pra alguém... Fiquei mais liberal"(Luiz Mello, 24 anos, estudante de Engenharia Elétrica, tem celular há três anos e meio).

"Eu uso o fixo
basicamente quando
eu tô em casa, e o
celular quando eu tô
na rua. Eu não uso o
celular em casa. [Se
ele toca em casa você
não atende?] Eu
atendo, mas aí não
sou em que pago, é a
pessoa que paga.
[Você não liga do
celular em casa?]
Não, a não ser que
seja, por exemplo, a
minha mãe tá no
telefone, aí eu preciso
falar urgentemente
com uma pessoa, não
tem problema, eu ligo"
(Vanessa Sá, 21 anos,
estudante de
Psicologia, tem celular
há mais ou menos três
anos].

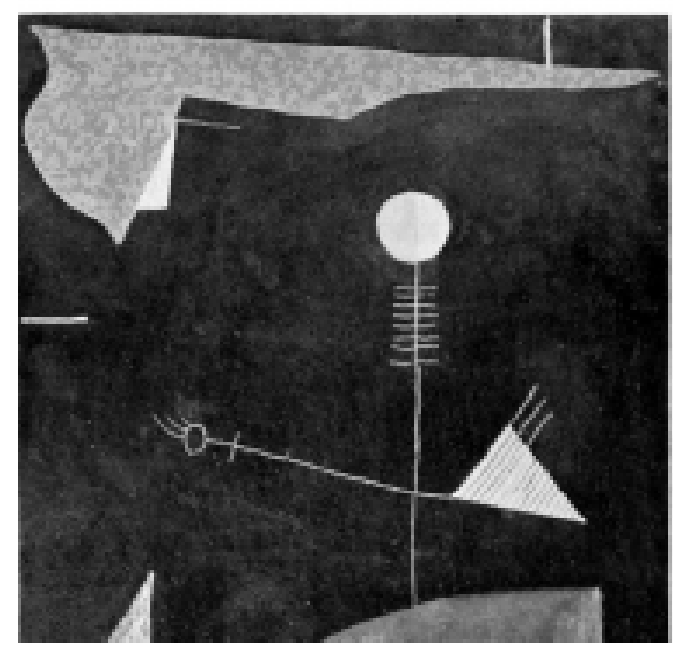

"Acho que ficou mais popular, né? Antigamente minha mãe tinha um celular que era de Minas Gerais, porque comprava mais barato. Depois, com esse negócio de cartão, o celular ficou bem popular. Todo mundo tem celular. Não é mais aquele acessório de luxo" (Francisco Nóbrega, 22 anos, trabalha como auxiliar de escritório, tem celular há quatro anos).

Embora essas mudanças sejam registradas, nossos resultados indicam que algumas coisas permaneceram inalteradas desde a chegada dos celulares ao Brasil. Uma delas é a sempre presente preocupação com os custos, ainda muito altos para bolsos jovens. Outra, indiretamente decorrente da primeira, é o discurso que delimita de forma automática e bastante rígida quando, onde e por quanto tempo telefones fixos ou celulares podem ou devem ser usados. De acordo com esse discurso, deve-se usar o telefone fixo (cujas tarifas são bem mais baixas) quando se está em casa. Já o celular (por conta das tarifas altas) deve ser usado exclusivamente da rua e para chamadas breves.

Esse discurso delimitador é, de fato, o primeiro a ser dado automaticamente como resposta à pergunta sobre as diferenças entre o telefone fixo e o celular pela maior parte dos nossos entrevistados. que se tente conhecer melhor o uso que esses

jovens fazem de seus celulares em casa para que surja um outro discurso, que contradiz o primeiro e joga por terra seus limites. Nesse outro discurso, ou contra-discurso, o uso do celular em casa aparece de duas formas diferentes: (a) os sujeitos falam sobre ele, abertamente, mas não de pronto, no que se refere às chamadas que recebem e pelas quais conseqüentemente não pagam e (b) no decorrer da entrevista, acabam admitindo fazer chamadas de seus celulares quando estão em casa, mas recorrem a várias situações de exceção para justificá-las. Seguem-se dois exemplos típicos:

"Eu uso o fixo basicamente quando eu tô em casa, e o celular quando eu tô na rua. Eu não uso o celular em casa. [Se ele toca em casa você não atende?] Eu atendo, mas aí não sou em que pago, é a pessoa que paga. [Você não liga do celular em casa?] Não, a não ser que seja, por exemplo, a minha mãe tá no telefone, aí eu preciso falar urgentemente com uma pessoa, não tem problema, eu ligo" (Vanessa Sá, 21 anos, estudante de Psicologia, tem celular há mais ou menos três anos).

"É...eu uso...tando fora de casa eu sempre uso o celular, nunca penso em pegar um cartão telefônico pra usar o orelhão. Agora, estando dentro de casa eu nem penso em usar o celular, tando dentro da minha casa eu uso sempre o telefone fixo. [E em casa você não usa?] É, não uso o celular em casa. [Nunca, em nenhuma situação?] Bom, eu uso o celular quando eu não quero que a pessoa saiba qual é o telefone da minha casa, que aí a pessoa fica só com o do meu celular e o celular eu controlo se atendo ou não. Deixa eu ver, e também acontece d'eu ligar do meu celular quando eu tô em casa, pô, lá em casa tá sempre alguém na internet ou falando no telefone, quando eu não tenho paciência de esperar eu vou e pego o celular mesmo. [Quando você quer ter uma conversa privada com alguém, em qual você prefere falar?] No celular, porque aí eu me tranco no quarto... e falo no celular mesmo. É mais uma situação que eu esqueci de comentar" (Luís Mello, 24 anos, estudante Engenharia Elétrica, tem celular há três anos e meio).

Isso acontece em praticamente todos os casos. Quando indagados sobre o uso que fazem do celular em casa, geralmente sua primeira resposta é a de que nunca o usam, sem qualquer tipo de qualificação. No entanto, ao continuarem a falar sobre o assunto, como aconteceu durante as entrevistas, eles logo admitem que recebem chamadas. É somente após algum tempo de esquiva que revelam usar o celular para ligar para os amigos quando estão em casa. Embora a grande maioria dos entrevistados mantenha seus celulares ligados 24 horas por dia (e alguns deles revelem chegar a carregá-los para o banheiro), o uso em casa para receber chamadas - que poderia ser facilmente 
admitido sem gerar problemas - não parece para eles contar como uso porque não envolve custos. Um outro aspecto do discurso delimitador exemplificado acima é o de que celulares devem ser usados para conversas curtas. É isso o que diz Juliana Araújo:

"Acho que celular é assim pra emergência. Celular não é pra ficar batendo papo" (Juliana Araújo, 22 anos estudante de Direito, tem celular há quatro anos).

\section{É também o que deixa claro Roberta França:}

“... celular é necessidade, muito dificilmente eu ligo por besteira... se for para ligar para minha casa eu ligo a cobrar e falo bem rápido" (Roberta França, 22 anos, estudante de Psicologia, tem celular há dois anos).

Além de estar associado aos ainda altos custos, o uso dos celulares para conversas rápidas parece remeter aos primeiros momentos de sua implantação, nos quais era freqüentemente vinculado a casos de necessidade, urgência ou emergência. Nesses primeiros momentos, muitos pais deram celulares aos filhos para que pudessem ter mais tranqüilidade, na medida em que poderiam localizá-los e ser por eles localizados em casos de necessidade ou emergência em uma cidade violenta como o Rio de Janeiro.

Naquela época, poucos tinham celulares, os aparelhos e serviços eram pouco atraentes, os custos eram exorbitantes e os jovens faziam deles um uso parcimonioso. Então, os telefones celulares tinham a principal função de transmitir segurança tanto a pais quanto a filhos. Essa função não desapareceu, como podemos ver nos depoimentos que se seguem.

Flávia Dantas acha muito bom ter um celular porque:

“... eu moro muito longe de onde eu estudo, de onde eu trabalho. Meus pais já se preocuparam muito com a minha demora, com o trânsito, violência. É para mim uma segurança, é de eu estar de repente num carro e acontecer alguma coisa e eu ter a quem chamar... É uma segurança" (Flávia Dantas, 22 anos, estudante e estagiária de Direito, tem celular há dois anos).

João Martins, embora não goste muito de carregar o celular para todos os lugares, afirma não dispensar seu uso por razões análogas:

“... não gosto muito de celular, de carregar, é importante, mas é meio chato. [Por que é importante?] Para a minha segurança... é sempre importante ter um celular na mão para o que der e vier" (João Martins, 18 anos, estudante de $2^{\circ}$ grau, tem celular há três anos).

Com a difusão da telefonia celular e o barateamento dos serviços, no entanto, a manutenção da segurança deixou de ser a função prioritária do uso de celulares. Praticamente todos os jovens passaram a tê-los e a usá-los nos mais diversos lugares e horas (inclusive em casa, como já vimos) para comunicar-se continuamente com os amigos e conhecidos. De acordo com o depoimento de Carla Nóbrega:

"No começo eu usava mais por necessidade,até porque meu pai dava e era ele que pagava...Era tipo assim, ele pagava e falava aquela coisa 'pô, toma cuidado, usa pro necessário', se precisou falar com alguém, se não, liga de casa. Então eu acho que eu cumpri muito mais isso. Hoje em dia não... Hoje sou eu que pago, não é meu dinheiro, é uma mesada que ele me dá na verdade, enfim,é meu porque eu administro aquele dinheiro. Daquele meu que eu tiro, entretanto se eu tiver no trânsito muito chato eu vou pegar pra bater papo, passar o tempo. Então, eu acho que meu uso] mudou. Eu não tenho mais aquela preocupação de só ligar o básico, necessário"(Carla Nóbrega, 21 anos, estudante de Psicologia, tem o celular há mais ou menos quatro anos).

Embora mais baratos, no entanto, os custos da telefonia celular ainda continuam altos. Por isso mesmo, o discurso da emergência, urgência ou necessidade parece persistir para justificar o uso bastante variado e pouco comedido que fazem de seus celulares nossos jovens entrevistados. Esse foi um dos resultados mais consistentes e interessantes da pesquisa, estando presente nos depoimentos de praticamente todos os entrevistados.

Bons exemplos desse discurso podem ser encontrados nas respostas de Felipe Mattoso e Bianca Falcão. Felipe afirma usar o celular somente para emergências:

“As situações básicas de eu usar o celular são emergências, quando geralmente eu preciso ligar pra alguém, naquela hora que eu não estou em casa, entendeu?" (Felipe Mattoso, 24 anos, estudante de Informática, tem celular há mais ou menos quatro anos).

E o que é uma emergência para ele?

"Emergência é a gente ter que encontrar [alguém] em algum lugar, alguma hora, e pra entregar um trabalho. Isso pra mim é uma emergência."

De modo análogo, Bianca declara usar seu celular principalmente para situações de emergência, pois celular não é para ficar batendo papo: 
"Eu uso o celular ... principalmente pra emergência, quando eu tô fora de casa, ligar pra minha mãe, avisar alguma coisa ... Celular é mais pra emergência. Não pra ficar conversando, batendo papo (Bianca Falcão, 21 anos, estudante de Medicina, tem celular há dois anos e meio).

Também para ela, emergência tem um significado peculiar que rompe com sua definição tradicional. De acordo com esse novo significado, um malestar, por exemplo, surpreendentemente deixa de ser prioritário:

"Emergência é tipo, avisar pra minha mãe onde eu tô, pra onde eu vou, ou, caso mesmo se ela tiver que me buscar em algum lugar, ou se eu tiver passando mal mesmo, aí tudo isso eu uso o celular".

Esse novo significado parece ser o mesmo dado a urgência ou emergência pela maioria dos entrevistados. Vanessa Sá descreve bem o que parece ter acontecido, quando comenta a necessidade que hoje se tem de falar com os outros imediatamente:

"É uma coisa mais recente isso... porque antigamente não existia celular e as pessoas ligavam pra outra, se tivesse ocupado fazer o que, né? Ligava depois. Mas aí, depois que apareceu o celular já tem essa... essa vontade de falar com a pessoa naquele segundo, mesmo que não seja uma coisa imediata, nada especial, mas quando você liga pra uma pessoa você quer falar com ela a todo o custo... Às vezes não é nem uma coisa emergência, mas por exemplo, aconteceu uma coisa comigo e eu quero falar com a minha amiga urgentemente. Aí, eu ligo pro celular dela. Mas às vezes eu espero pra ligar de noite, quando eu sei que eu vou ficar falando algum tempo com a pessoa" (Vanessa Sá, 21 anos, estudante de Psicologia, tem celular há mais ou menos três anos). Essa é, portanto, segundo a própria Vanessa, uma urgência não urgente.

São, contudo, os depoimentos de Sandra Romero e Roberta França que tornam evidente o confuso processo de redefinição do que é uma emergência.

"É, telefone celular, eu, eu ligo, sei lá, a princípio mais por urgência, mas às vezes eu ligo para alguém e acabo esquecendo que liguei do celular, tipo passo um tempão no celular" (Sandra Romero, 18 anos, estudante de Biomedicina, tem celular há três anos e meio).

"Hoje é mais emergência, mais necessidade, o uso numa necessidade, não emergência que parece que aconteceu alguma coisa. Assim, às vezes um avisar alguém de alguma coisa é uma necessidade"
Passamos, portanto, pela urgência não urgente de Vanessa Sá e pela urgência que leva a um papo de horas de Sandra Romero para finalmente chegarmos à emergência que não é uma "emergência que parece que aconteceu alguma coisa" de Roberta França. Emergência e urgência parecem ter sofrido redefinições.

\section{Discussão}

Os resultados acima tornam evidente que características da modernidade e da pósmodernidade coexistem não somente no plano social. Essa coexistência aparece nitidamente nas várias contradições que permeiam os depoimentos dos nossos entrevistados, o que indica estar presente no íntimo desses jovens sujeitos.

Um bom exemplo da influência da modernidade sobre esses sujeitos é o discurso que delimita com precisão onde, quando e por quanto tempo os telefones fixos e os celulares devem ser usados. Esse discurso, que, como foi visto, está aparentemente pronto para consumo, parece ser originário das demarcações que geravam a solidez e as estrias do tecido moderno, das quais nos falam Bauman (2001) e Deleuze \& Guattari (1997) respectivamente. Nele, enquanto o telefone fixo é vinculado ao uso em casa para conversas curtas ou longas, o celular é vinculado ao uso na rua somente para conversas curtas. Esses dois tipos de uso parecem ser separados um do outro por membranas impermeáveis como aquelas descritas por Meyrowitz (1999) e discutidas anteriormente. O discurso moderno é, no entanto, desconstruído pelo relato que os mesmos sujeitos fazem a respeito de sua prática pós-moderna de uso de telefones celulares. Nessa prática, não há lugares nem tempo determinados para nada. Tudo passa a ser fluido e liso, como é característico da pós-modernidade (novamente de acordo com Bauman e Deleuze \& Guattari). As membranas impermeáveis, que o discurso do "fixo em casa" sugeria existirem entre os usos de telefones fixos e celulares, provam já se terem tornado porosas o suficiente para permitir a interpenetração de usos e espaços.

Já o discurso da "emergência", ao qual se contrapõe a intensa sociabilidade à distância dos nossos jovens entrevistados, revela algo mais do que uma contradição. Sua análise permite entrever um processo de diluição e fusão de significados que leva à interpenetração de campos semânticos, cujas membranas, antes impermeáveis, também se tornaram porosas. Vejamos em detalhe como isso pode ser captado. Comecemos pela contradição. Como já foi dito na seção anterior, o discurso da "emergência", "urgência" e "necessidade" tem sua origem nos primeiros tempos da implantação dos celulares no Brasil, quando estes ainda eram pouco 
difundidos e muito caros. Naqueles tempos, os pais davam celulares a seus filhos para que estes os usassem em casos de emergência, urgência ou necessidade tradicionais. Assim sendo, mesmo na época em que tanto os aparelhos quanto os serviços de telefonia celular tinham custos exorbitantes, o discurso da "emergência", "urgência" e "necessidade" legitimava o uso dos celulares em praticamente todos os lugares e horas.

Os tempos mudaram, os celulares se difundiram e seus serviços tornaram-se mais baratos, ou melhor, menos caros. Serviços menos caros levaram, porém, à instauração, entre os jovens, de um estilo de vida no qual o celular é constantemente usado para a manutenção de uma fluida e densa rede de sociabilidade. Desse modo, do ponto de vista de quem paga a conta (geralmente os pais), serviços mais baratos não reduziram os custos. Essas razões financeiras fazem com que pais e mães continuem insistindo na necessidade de um uso parcimonioso do celular por parte de seus filhos. Estes, no entanto, já haviam aprendido que sempre poderiam se valer da legitimação dada ao seu uso cada vez menos comedido pelo discurso da "emergência", "urgência" e "necessidade", e, mesmo nas entrevistas, continuam a valer-se desse discurso até o momento em que revelam sua prática de uso cotidiano.

A utilização desse discurso, contudo, parece ter conseqüências mais duradouras e profundas do que se pode supor à primeira vista. As contradições detectadas entre o discurso do uso para emergências e a intensa e praticamente ininterrupta prática de manutenção de uma fluida rede social permitem apreender um interessante processo de interpenetração de campos semânticos. Repassemos brevemente o que já foi visto para torná-la clara.

Quando os pais deram os celulares aos filhos, buscavam a segurança destes, segurança essa que estava intimamente associada a situações tradicionais de emergência ou necessidade (como pequenos e grandes acidentes no trânsito, malestares inesperados etc.). Os celulares tornaramse, portanto, uma garantia da segurança dos jovens e da tranqüilidade dos pais.

Os jovens absorveram tanto essa sensação de (relativa) segurança quanto o discurso de seus pais sobre o uso de celulares somente para casos de emergência, urgência e necessidade convencionais. Com a difusão da telefonia celular, porém, esses mesmos jovens passaram a deixar de lado essa restrição e a usar seus celulares primordialmente para manter contato constante com amigos, namorados, conhecidos etc. No entanto, dado que seus pais continuavam (e continuam) a insistir em alguma forma de contenção de custos, passaram a recorrer ao discurso da "emergência", "urgência" e "necessidade" para justificar seus excessos.

À primeira vista, essa série de pequenas transformações discursivas poderia ser qualificada como apenas mais uma instância da capacidade de manipulação de que os jovens costumam ser capazes quando querem alguma coisa. Contudo, no atual contexto pós-moderno descrito na introdução deste trabalho, essas transformações podem indicar muito mais do que uma simples manipulação. Nesse contexto, no qual fronteiras são diluídas e a experiência se torna fluida porque as membranas que separavam o que "era" do que "não era" estão se tornando cada vez mais permeáveis, esse conjunto de pequenas manobras parece estar tendo conseqüências mais permanentes e profundas, isso porque um outro importante deslizamento de significado se soma àqueles já mencionados. Este último é decorrente daquela que é quase unanimemente apontada como característica distintiva da pós-modernidade: a do imediatismo (ver, entre outros, Jameson, 1991, Bauman, 1997, 2001, Harvey, 1989, Eagleton, 1996, Sennett, 1998).

$\mathrm{Na}$ realidade, em vários dos depoimentos coletados, fica claro que nossos sujeitos partem do pressuposto de que seu desejo de contato com os outros deve ser imediatamente satisfeito. O imediatismo pós-moderno parece, portanto, exercer influência sobre eles. Minimamente, parece levá-los a equacionar a satisfação imediata de seu constante desejo de contato com os outros às respostas e ações imediatas geradas por situações tradicionais de emergência, urgência ou necessidade (que geralmente envolvem risco). É isso o que o depoimento de Vanessa Sá, citado na seção anterior, indica exemplarmente quando faz referência ao fato de ela insistir em falar "imediatamente com quem deseja mesmo não sendo uma coisa de emergência". Essa também parece ser a razão que leva Roberta França a fazer a confusa afirmação de que usa seu celular em situações de emergência que não se qualificam como "emergência que parece que aconteceu alguma coisa".

Uma consulta ao tradicional Dicionário Aurélio (1975) mostra que as falas "prontas" dos nossos entrevistados se encaixam bastante bem em três campos semânticos, que eram distintos no período moderno.

Nesse período, segurança e tranqüilidade davam cobertura a um mesmo campo semântico. Segurança passava a idéia de garantia, de seguro, enquanto tranqüilidade sugeria significados 
semelhantes: paz de espírito, calma, ordem etc. Aí se encaixam as razões para que os pais equipassem seus filhos com aparelhos celulares.

De forma análoga, um outro campo semântico era composto por conceitos como: necessidade (aquilo que é absolutamente necessário, que constrange, compele ou obriga de modo absoluto), urgência (situação em que algo é necessário e deve ser feito com rapidez) e emergência (situação de urgência, situação crítica, acontecimento perigoso ou fortuito). Aí se encaixa o discurso da urgência, emergência e necessidade convencionais.

Esses dois campos semânticos independentes eram bastante distintos do campo semântico leigo coberto pela palavra "desejo" (vontade de possuir ou de gozar, anseio, aspiração), no qual se encaixa a "vontade" (desejo, decisão ou determinação expressa) de ter contato com os outros nas situações mais variadas por meio dos celulares, repetidamente manifestadas por nossos entrevistados.

Acontece, porém, que, no período moderno, podia-se esperar. Desse modo, o campo semântico coberto pelas palavras "desejo" e "vontade" estava em grande parte associado ao adiamento da sua satisfação. Já no período pós-moderno, vivemos sob a égide do imediatismo. Em um mundo veloz e voraz, tudo tem que ser fruído instantaneamente. Esse imperativo da instantaneidade parece explicar o que está por trás dos depoimentos que colhemos. Uma diluição de fronteiras gerou a fusão dos campos semânticos de segurança/tranqüilidade e urgência/emergência/necessidade. Esse processo de diluição e fusão, que ocorreu por razões bastante pragmáticas, deu origem ao discurso da urgência, emergência ou necessidade tradicionais, usado por pais e filhos para legitimar o uso de celulares por parte dos nossos jovens sujeitos em um primeiro momento.

Em um segundo momento, esse mesmo discurso passou a ser usado pelos jovens para justificar seus excessos no uso de celulares. Ocorreu, então, um outro interessante processo de diluição e fusão de campos semânticos. Por conta do imperativo da instantaneidade contemporâneo, no caso dos nossos entrevistados, os significados modernos de necessidade, urgência e emergência fundiram-se aos significados pós-modernos de "necessidade", "urgência" ou "emergência" de satisfação do desejo de contato com os outros, devido ao fato de esses se terem tornado adultos em um mundo no qual a satisfação de desejos e vontades tornou-se uma "necessidade que requer satisfação imediata" e não é difícil associar - "necessidades que requerem ações imediatas" configuram-se como urgências ou emergências.

Os resultados apresentados indicam que estamos diante da interpenetração de campos semânticos, cujas membranas se tornaram porosas, assim permitindo que os significados passassem a fluir de um para outro livremente. Muito provavelmente, são processos como esse, que tivemos a felicidade de captar, que estão dando à pós-modernidade suas características fluidas e lisas.

\section{Considerações Finais}

Nisbet (1966) relata uma interessante observação do historiador Eric Hobsbawn. Segundo ele, Hobsbawn afirmava que palavras falam mais alto do que documentos. Com isso, queria dizer que mudanças radicais ganham concretude nas palavras que são cunhadas ou têm seus significados modificados para descrever uma nova realidade. Por essa razão, Nisbet assinala, o período de mudanças radicais gerado pela Revolução Industrial e pela emergência do capitalismo (compreendido entre o final do século XVIII e a primeira metade do século XIX) foi um dos mais ricos na formação de novas palavras e na transformação do significado de antigas (ver, também, Nicolaci-da-Costa, 2002a). Parece que estamos diante de uma nova versão desse mesmo tipo de fenômeno. A diferença é que, enquanto nos casos anteriores a mudança de significados foi registrada depois de ter sido consolidada, no presente caso, o próprio processo de transformação dos significados pôde ser tornado visível. 
BAUMAN, Z. O Mal-estar da Pós-modernidade. Rio de Janeiro: Jorge Zahar.,1997.

Modernidade Líquida. Rio de Janeiro: Jorge Zahar,2001.

CASTELLS, M. A Sociedade em Rede. São Paulo: Paz e Terra, 2000.

DELEUZE, G. \& GUATTARI, F. Mil Platôs: Capitalismo e Esquizofrenia, vol. 5. São Paulo: Editora 34,1997.

EAGLETON, T. As Ilusões do Pós-modernismo. Rio de Janeiro: Jorge Zahar,1996.

FERREIRA, A. B. H. Novo Dicionário Aurélio. Rio de Janeiro: Nova Fronteira, 1975

GIDDENS, A. Mundo em Descontrole. Rio de Janeiro: Record,2002.

HARVEY, D. Condição Pós-moderna. São Paulo: Loyola,1989.

JAMESON, F. Pós-modernismo: a Lógica Cultural do Capitalismo Tardio. São Paulo: Ática,1991.

KOPOMOAA, T. Speaking Mobile: the City in Your Pocket. Helsinki: Gaudeamus,2000.

LABOV, W. The Logic of Nonstandard English. In Labov, W., Language in the Inner City. Philadelphia: University of Pennsylvania Press, 1972, pp. 201-240.

LEITÂO, C. \& NICOLACI-da-COSTA A. M. Psicologia Clínica e Informática: por que Essa Inusitada Aproximação? Psicologia Clínica, 12 , no 2, 2000,pp.189-205.

A Psicologia no Novo Contexto Mundial. Estudos de Psicologia (UFRN), 2003 ( no prelo).

LEITÃO, C. Os Impactos Subjetivos da Internet: Reflexões Teóricas e Clínicas. Tese de Doutorado não-publicada, Curso de Pós-Graduação em Psicologia Clínica, Pontifícia Universidade Católica do Rio de Janeiro. Rio de Janeiro,2003.

LYOTARD, J. F. A Condição Pós-moderna. Rio de Janeiro: José Olympio, 1979.

MEYROWITZ, J. Global Permeabilities. In Larreta, E.R. (org.). Media and Social Perception. Rio de Janeiro: UNESCO, ISSC, EDUCAM,1999,pp.423-441.
NICOLACI-da-COSTA, A. M. Revoluções Tecnológicas e Transformaçóes Subjetivas. Psicologia: Teoria e Pesquisa, 18, nำ2,2002 a, pp.193-202.

. Internet: a Negatividade do Discurso da Mídia Versus a Positividade da Experiência Pessoal. À qual Dar Crédito? Estudos de Psicologia (UFRN), 7, n 1,2002b,pp. 25-35.

Quem Disse que é Proibido Ter Prazer Online. Identificando o Positivo no Quadro de Mudanças Atual. Psicologia: Ciência e Profissão, 22, no 2,2002c,pp. 12-21.

. A Análise de Discurso em Questão. Psicologia: Teoria e Pesquisa, 10, no 2, 1994,pp.317-331.

Questões Metodológicas Sobre a Análise do Discurso. Psicologia: Reflexão e Crítica, 4, $n^{\circ}$ 1/2, 1989,pp.103-108.

NISBET, R .A. The Sociological Tradition. New York: Basic Books,1996.

PLANT, S. On the Mobile: the effects of Mobile Telephones on Social and Individual Life. http://www.motorola.com/mot/documents/ 0,1028,296,00.pdf,2002 [Acesso em maio de 2002].

RHEINGOLD, H. Smart Mobs: the Next Social Revolution. Cambridge, Mass.: Perseus Books, 2002.

ROBERTS, CRABTREE \& NATHAN, S; CRABTREE, I. \& NATHAN, M. MobileUK - Mobile Phones and Everyday Life. Isociety. http:// www.theworkfoundation.com/research/isociety/MobileUK_main.jsp [Acesso em março de 2003].

ROMÃO-DIAS, D. Nossa Plural Realidade: um Estudo Sobre a Subjetividade na Era da Internet. Dissertação de Mestrado nãopublicada, Curso de Pós-Graduação em Psicologia Clínica, Pontifícia Universidade Católica do Rio de Janeiro. Rio de Janeiro,2001.

SENNETT, R. A Corrosão do Caráter: Conseqüências Pessoais do Trabalho no Novo Capitalismo. Rio de Janeiro: Record,1998.

TURKLE, S. Life on Screen: Identity in the Age of the Internet. New York: Touchstone Edition, 1995.

VATTIMO, G. O Fim da Modernidade: Niilismo e Hermenêutica na Cultura Pós-moderna. São Paulo: Martins Fontes, 1985.

VIRILIO, P. O Espaço Crítico. São Paulo: Editora 34,1993. 